\begin{abstract}
Iranica
Abstracta Iranica Revue bibliographique pour le domaine irano-aryen

Volume 32-33 | 2013

Comptes rendus des publications de 2009-2010
\end{abstract}

\title{
Manfred Brust. Die indischen und iranischen Lehnwörter im Griechischen
}

\section{Rüdiger Schmitt}

\section{(2) OpenEdition \\ 1 Journals}

\section{Electronic version}

URL: http://journals.openedition.org/abstractairanica/40115

DOI: 10.4000/abstractairanica.40115

ISSN: 1961-960X

Publisher:

CNRS (UMR 7528 Mondes iraniens et indiens), Éditions de l'IFRI

\section{Printed version}

Date of publication: 1 December 2013

ISSN: 0240-8910

\section{Electronic reference}

Rüdiger Schmitt, « Manfred Brust. Die indischen und iranischen Lehnwörter im Griechischen », Abstracta Iranica [Online], Volume 32-33 | 2013, document 11, Online since 01 July 2016, connection on 26

September 2020. URL : http://journals.openedition.org/abstractairanica/40115 ; DOI : https://doi.org/ 10.4000/abstractairanica.40115

This text was automatically generated on 26 September 2020.

Tous droits réservés 


\title{
Manfred Brust. Die indischen und iranischen Lehnwörter im Griechischen
}

\author{
Rüdiger Schmitt
}

\section{REFERENCES}

Manfred Brust. Die indischen und iranischen Lehnwörter im Griechischen. 2., verbesserte und vermehrte Auflage. Innsbruck, Institut für Sprachen und Literaturen der Universität Innsbruck, 2008, LXI + 721 p. (Innsbrucker Beiträge zur Sprachwissenschaft, Band 118).

1 The first edition of this book, published in 2005, provided, for the first time, a rather complete description of Iranian (and Indo-Aryan) loanwords in ancient Greek. These words were examined philologically and linguistically. Iranian and Indo-Aryan loanwords were dealt with together since most of the latter found their way into Greek through contacts with Iran. Some words attested only by later (Byzantine) lexicographers were missing, as were several others that lack a convincing (Iranian) etymology but are, for one reason or another, of Iranian origin. The wide-ranging but detailed grammatical discussion had considerable weaknesses. It is, therefore, good news to learn that a "corrected and augmented" new edition has come out so soon

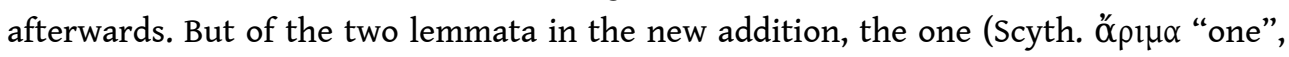
once in Herodotus) is a mere Greek etymological fabrication, whereas the other

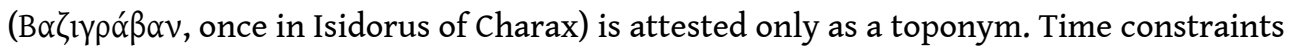
have kept the author from correcting the many points that critics previously made (e.g., those by this reviewer in Kratylos 52, 2007, p. 76-86). For this reason, the new edition has barely improved on the initial version. 


\section{AUTHORS}

\section{RÜDIGER SCHMITT}

Laboe 